Original Article

\title{
ISOLATION OF CUCURBITACIN-B FROM CUCUMIS CALLOSUS AND ITS HYPOGLYCEMIC EFFECT IN ISOLATED RAT ENTEROCYTES
}

\author{
SIVA PRASAD PANDA ${ }^{*}$, ASIT KUMAR SARANGI ${ }^{2}$, UTTAM PRASAD PANIGRAHY ${ }^{3}$
}

${ }^{1}$ KL College of Pharmacy, KLEF Deemed to be University, Vaddeswaram, Guntur, India, ${ }^{2}$ College of Pharmaceutical Sciences, Puri, Odisha, India, ${ }^{3}$ KL College of Pharmacy, KLEF Deemed to be University, Vaddeswaram, Guntur, India

Email: sivaprasad.panda@kluniversity.in

Received: 08 Mar 2018 Revised and Accepted: 11 Apr 2018

\section{ABSTRACT}

Objective: The pericarp of fruits of Cucumis callous (Rottl.) Cogn. (Cucurbitaceae) is traditionally used for curing diabetes, epilepsy, and diarrhea. It has an active compound include Cucurbitacin-B (CuB), which acts as a potent inducer of CYP450 of rat enterocytes. This study was conducted with the aim of elaborating and reconciling our previous finding on the glucose-lowering effect of Cucumis callosus (Rottl.) Cogn. fruits.

Methods: In vivo hypoglycemic potential for methanolic pericarp extracts from $C$ callosus (MPCC, $350 \mathrm{mg} / \mathrm{kg}$ b.w. p. o), methanolic seed extract of $C$ callosus (MSCC, $250 \mathrm{mg} / \mathrm{kg}$ b.w. p. o) and CuB $(80 \mu \mathrm{g} / \mathrm{kg}$ b.w. p. o) were studied in streptozotocin (STZ, $55 \mathrm{mg} / \mathrm{kg}$ b.w. i. p) induced diabetic rats. Metformin (25 mg/kg b.w. p. o) served as reference drug. Ex vivo model of intestinal tissue preparation of Swiss albino rats named Single Pass Intestinal Perfusion (SPIP) technique was performed for ex vivo hypoglycemic study. The glucose levels in the serosal fluid were determined by commercially available glucose oxidase kit and compared with the standard drug metformin $(0.1 \mathrm{mg} / \mathrm{kg})$.

Results: In vivo results showed that administration of MPCC $(350 \mathrm{mg} / \mathrm{kg}$ b.w. p. o) and Cucurbitacin-B $(80 \mu \mathrm{g} / \mathrm{kg}$ b.w. p. o) produced the hypoglycemic effect. The MPCC $(1.4 \mathrm{mg} / \mathrm{kg})$ and CuB $(0.4 \mu \mathrm{g} / \mathrm{kg})$ produced hypoglycemic effect in ex vivo technique. These effects are due to induction of $0.53 \mathrm{~m} \mu$ moles of CYP450 proteins with maximum absorption at $454 \mathrm{~m} \mu$ in rat enterocytes.

Conclusion: The present investigation gave evidence that bitter pericarp of $C$ callosus fruit has a hypoglycemic effect due to the presence of Cucurbitacin B as phytoconstituent but seeds did not have such effects.

Keywords: Cucumis callosus, Cucurbitacin-B, CYP450, Metformin

(C) 2018 The Authors. Published by Innovare Academic Sciences Pvt Ltd. This is an open access article under the CC BY license (http://creativecommons.org/licenses/by/4.0/] DOI: http://dx.doi.org/10.22159/ijpps.2018v10i5.25788

\section{INTRODUCTION}

Hyperglycemia is the net result of glucose influx exceeding glucose outflow of the plasma compartment. Abnormal islet cell function is a key and requisite feature of hyperglycemia $[1,2]$. The chronic hyperglycemia is associated with long-term damage, dysfunction and eventually the failure of organs, especially the eyes, kidneys, nerves, heart, and blood vessels $[3,4]$. The management of diabetes is a global problem until now and successful treatment is not yet discovered [5]. Treatment of oral hypoglycemic agents is associated with side effects related to pharmacokinetic properties, secondary failure rates, hypoglycemia, gastrointestinal disturbances, skin reactions, haematological disorders, and rise in hepatic enzyme level $[6,7]$. Hypoglycemic herbs are widely used as a non-prescription treatment for diabetes. However, few herbal medicines have been well characterized and demonstrated the efficacy in systematic clinical trials as those of Western drugs [8].

Herbal medicines (HMs) with a bitter flavor and cold property may have multiple antidiabetic mechanisms and have exact antidiabetic effect with small toxic/side effect compared with western drugs. HMs with same property can be a complementary and alternative treatment for DM $[9,10]$. Cucumis callosus (Rottl.) Cong. (FamilyCucurbitaceae) is a highly branched perennial herb, mostly distributed over northern and eastern part of India [11-13]. Fruits are commonly known as Bitter Cucumber in English, Kachri in Hindi and Karkati in Sanskrit. The pericarp of fruit is very bitter taste than endocarp. Seeds are tasteless. The fruit is useful in jaundice, cerebral congestion, colic, constipation, dropsy, fever, worms, and sciatica $[14,15]$. Root is given in cases of abdominal enlargement, cough, asthma, inflammation of the breast, ulcers, urinary diseases and rheumatism (16). The leaf extract is topically used in Wound healing [17]. The methanol extract from fruits has been reported on its antidiabetic, antioxidant and antihyperlipidemic activity [18]. The oil from seeds is used for poisonous bits, bowel. Complaints, epilepsy and also for blackening the hair [19]. In India (Eastern Odisha and West Bengal), ripe fruits are eaten raw and used in curries, green fruit used as a vegetable, dried pericarp of fruits used to control blood sugar level [20].

The objective of the investigation was to isolate lead molecules from methanolic pericarp extract of $C$ callosus (MPCC) and to explore there in vivo and ex vivo effects on plasma glucose.

\section{MATERIALS AND METHODS}

Ethics statement

All the experiments were conducted in compliance with the guidelines of Ethics Committee of the International Association for the Study of Pain and with the approval of the Institutional Animal Ethical Committee (IAEC) of our University (KLPIAEC10/07/1702)

\section{Drugs and chemicals}

STZ, metformin were purchased from Himedia, Mumbai, India. The CuB was dissolved in DMSO to make $200 \mu \mathrm{M}$ stock solution and kept at $-20{ }^{\circ} \mathrm{C}$. The stock solution was freshly diluted to the desired concentration just before use. All other reagents used were of analytical grade obtained from Merck specialties Private Limited, Mumbai, India.

\section{Plant material and extract preparation}

The $C$. callosus fruits ( $15 \mathrm{~kg}$ ) were collected in the month of August 2017 from village area of Kendrapara and Balasore district, Odisha (India). The plant was authenticated by M. S. Mondal, Botanical Survey of India, Kolkata, India, and a voucher specimen (CNH/1$1(196) / 2007 /$ Tech-II/160) has been preserved in the Pharmacology Research Laboratory, Jadavpur University, Kolkata for future reference. All fruits were shade dried with separation of seeds and pericarp. The dried seed powder $(200 \mathrm{~g})$ and pericarp powder $(800$ 
g) were defatted with petroleum ether at $40{ }^{\circ} \mathrm{C}$ in a Soxhlet extraction apparatus and then extracted similarly with methanol. Methanol solvent was completely removed under reduced pressure to obtain a dry mass. Yields of extracts were found to be $1.8 \% \mathrm{w} / \mathrm{w}$ and $7.6 \% \mathrm{w} / \mathrm{w}$, respectively. Both extracts were stored in vacuum desiccators for further use. The preliminary phytochemical screening of both products showed the presence of mainly flavonoids, saponin, and triterpenoids [21].

\section{Thin layer chromatographic analysis (TLC) of the extract}

Commercial aluminum sheets silica gel 60F254 of $0.2 \mathrm{~mm}$ thickness (Merck, Art. 5554) plates of size $4 \mathrm{~cm} \times 10 \mathrm{~cm}$ were used. The plant extracts were diluted with distilled water and applied onto the TLC plates by using fine glass capillaries to fine $1 \mathrm{~cm}$ bands. Plates were let to dry completely and developed in the saturated chromatographic chamber with various solvent systems to a distance of $8.5 \mathrm{~cm}$ at room temperature. All separated bands of compounds were analyzed by viewing under visible and $\mathrm{UV}_{254}$ lights, spraying with Vanillin $/ \mathrm{H}_{2} \mathrm{SO}_{4}, \mathrm{FeCl}_{3}$, and DPPH spraying reagents. The $\mathrm{R}_{\mathrm{f}}$ value of each separated band was calculated.

\section{Column chromatographic, UV and FTIR analysis of the extract}

On the foundation of phytochemical screening and TLC study, isolation was done by column chromatography through isocratic elution technique with the help of solvent system Chloroform and ethyl acetate (9:1). Fractions were collected in small conical flasks and the rate of flow of mobile phase was restricted to 40 drops per minute. The isolated compounds were further characterized by UV and FTIR studies $[22,23]$. FTIR analysis of the extract was carried out by $\alpha$ E BRUKER FTIR model.

\section{Acute toxicity study}

MPCC, MSCC, and CuB were administered orally to male Swiss albino mice to find out the $\mathrm{LD}_{50}$ dose [24].

\section{In vivo hypoglycemic study}

\section{Induction of Experimental diabetes}

The rats were rendered diabetic by a single intraperitoneal dose of $55 \mathrm{mg} / \mathrm{kg}$ b.w. STZ freshly dissolved in ice-cold $0.1 \mathrm{M}$ citrate buffer $(\mathrm{pH} 4.5)$. After $72 \mathrm{~h}$, fasting blood glucose (FBG) levels were measured and only those animals showing blood glucose level $\geq 225$ $\mathrm{mg} / \mathrm{dl}$ were considered for the present investigation. The day on which hyperglycemia had been confirmed was designated as day 0 .

\section{Determination of fasting blood glucose (FBG) level in STZ induced diabetic rats}

Thirty-six male Wistar albino rats (180-200 g) were divided into six groups $(n=6)$. The first group served as the normal non-diabetic control (saline control). Group II served as the diabetic control (STZ control). Groups III, IV, V and VI received MPCC (350 mg/kg b.w. p. o), MSCC (250 mg/kg b.w. p. o), CuB (80 $\mu \mathrm{g} / \mathrm{kg}$ b.w. p. o) and Metformin ( $25 \mathrm{mg} / \mathrm{kg}$ b.w. p. o) respectively for 15 consecutive days. Blood glucose levels were measured on every 5 th day during $15 \mathrm{~d}$ by using a digital balance and one-touch glucometer (Accu-Chek®).

\section{Ex vivo hypoglycemic study}

\section{Preparation of perfusion solutions}

The perfusion buffer composition was as follows: $\mathrm{CaCl}_{2} \times 2 \mathrm{H}_{2} \mathrm{O}, 0.98$ mmol, KCl $2.58 \mathrm{mmol}, \mathrm{Na}_{2} \mathrm{HPO}_{4} 0.66 \mathrm{mmol}, \mathrm{NaH}_{2} \mathrm{PO}_{4} 5.1 \mathrm{mmol}$, $\mathrm{NaCl} 84 \mathrm{mmol}$, d-glucose $3.0 \mathrm{mmol}$ with pH 6.8 (with $\mathrm{NaOH}$ ) phenol red $\left(50 \mathrm{mg} \mathrm{L}^{-1}\right)$ was added to the solution as a non-absorbable marker. The $\mathrm{pH}$ was adjusted to 7.4 [25]. Preliminary experiments showed that there was no adsorption of the compounds to the catheters and the tubing. Test drug concentrations used in the perfusion studies were selected by dividing the therapeutic dose of the drug $(350 \mathrm{mg} / \mathrm{kg})$ by the accepted gastric volume $(250 \mathrm{ml})$, so as to represent maximal concentration in the intestinal segment [26].

\section{SPIP technique for evaluation of intestinal glucose uptake}

Single Pass Intestinal Perfusion (SPIP) studies were performed in Swiss albino rats after intraperitoneal injection of $25 \mathrm{mg} / \mathrm{kg}$ of thiopental sodium [27]. Animal care and handling throughout the experimental procedure were performed in accordance with the CPCSEA, India guidelines. After the onset of deep anaesthesia, the abdomen was opened by a midline longitudinal incision, and approximately $15 \mathrm{~cm}$ length of intestine immediately after stomach was selected, rinsed with frogs' ringer solution and cannulated on both sides. Care was taken in handling the small intestine to minimize the blood loss. Thirty male Wistar albino rats $(180-200 \mathrm{~g})$ were divided into five groups $(\mathrm{n}=6)$. Rats were fasted for $24 \mathrm{~h}$ prior to the start of the experiment. The group I served as the normal saline control group. Group II, III and IV received MPCC $1.4 \mathrm{mg} / \mathrm{kg}$ b.w., MSCC $1 \mathrm{mg} / \mathrm{kg}$ b.w., and CuB 0.4 $\mu \mathrm{g} / \mathrm{kg}$ b.w. respectively for 1 hour. Group $\mathrm{V}$ received the reference drug metformin $0.1 \mathrm{mg} / \mathrm{kg} \mathrm{b}$. w for 1 hour. The glucose concentration of serosal fluid was calculated in all groups using the parallel-tube model (fig. 1) [28]. For studying the effect of the test compound on glucose (substrate) uptake, glucose was added into mucosal compartment fluid just before the start of the experiment. At the end of the incubation period $(1 \mathrm{~h})$, the sacs were removed from the flask and these sacs were emptied and the serosal fluid from the sacs was used for the estimation of glucose. Similar estimations were also performed on samples of mucosal fluid in the flasks. Glucose concentrations were measured using a commercially available glucose oxidase kit (Lifechem TM-GlucoseLR). The loss of glucose from the mucosal fluid assumed to represent the glucose taken up by the intestine, and the rise in glucose in a serosal fluid, the glucose released. The difference is attributable to the glucose retained in the tissue. Amount of glucose transported from the mucosal compartment was characterized as "uptake" while the serosal gain of the substances is treated as "release". Uptake and release of glucose were expressed as PM/g tissue. Permeability for glucose in each group of rats was determined and the results were presented as mean $\pm S D$.

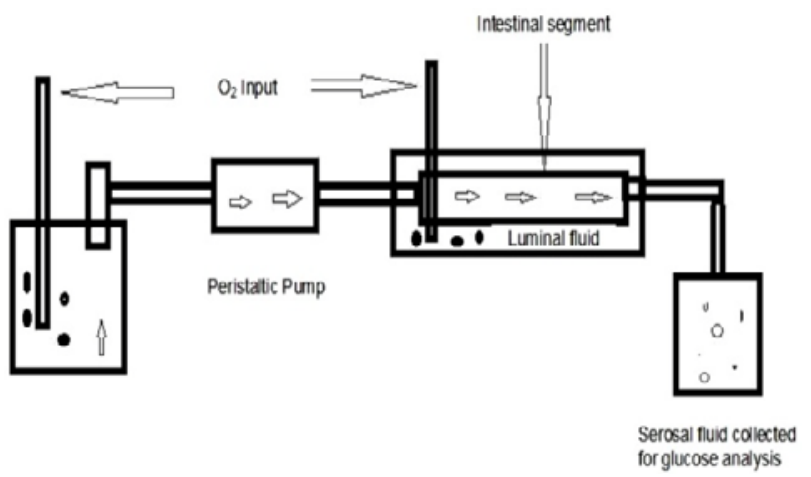

Fig. 1: Single-pass intestinal perfusion (SPIP) system preparation using parallel-tube model for ex vivo hypoglycemic study

\section{Kinetic study on ex vivo glucose uptake}

A kinetic study was conducted to understand the transport/ inhibition of glucose across intestinal membrane. In terms of enzyme kinetics, the amount of glucose transported/h was analog to the velocity of transfer, in other words, to the concentration difference of the glucose between compartments at the beginning and end of an experiment [29]. The Michaelis-Menten constant $\left(\mathrm{K}_{\mathrm{m}}\right)$, which is the affinity of the transferring enzyme (glucose transporter) for the substrate (glucose). The maximal velocity $\left(V_{\max }\right)$, which is the rate of transfer reaction in the presence as well as in the absence of the plant extracts was determined from the differences of the uptake and release values using Michaelis-Menten and the Line weaver-Burk Plots in Microsoft Excel. Comparison of difference between the control and experimental groups were examined using one-way analysis of variance (ANOVA). In each series of experiments, the controls were run either with or without test compound and results were corrected accordingly [30]. 


\section{Determination of cytochrome P450}

Swiss albino rats (200-240 g) were given single daily intraperitoneal injections of $100 \mathrm{mg} / \mathrm{kg}$ of sodium phenobarbital in normal saline for $3 \mathrm{~d}$. Control rats received an equal volume of normal saline. The animals were starved overnight and sacrificed on the $4^{\text {th }}$ day $(24 \mathrm{~h}$ after the last injection of phenobarbital). $25 \%$ of intestine homogenate in isotonic $\mathrm{KCl}-0.01 \mathrm{M}$ phosphate buffer was prepared and the microsomal fraction is isolated. Microsomes were washed by resuspending the pellet in ice-cold $1.15 \% \mathrm{KCl}$, recentrifuged at $100,000 \times \mathrm{g}$ for $60 \mathrm{~min}$. The washing procedure removes most of the hemoglobin. The microsomal fraction isolated from the intestine (wet weight) were suspended in $6.0 \mathrm{ml}$ of $0.05 \mathrm{M}$ phosphate buffer, pH 7.6 (EDTA) and kept for protein concentration measurement. The protein concentration of this suspension is measured as 2.5 $\mathrm{mg} / \mathrm{ml}$. All subsequent procedures are done at room temperature. 2 $\mathrm{ml}$ of the suspension is placed into each of two matched cuvettes with either Teflon or glass stoppers. A baseline is determined using the recording spectrophotometer (ROLEX) by scanning from 400 $500 \mathrm{~m} \mu$. Carbon monoxide is bubbled gently into the sample cuvette for $20 \mathrm{sec}$. A few milligrams of solid sodium dithionite $\left(\mathrm{Na}_{2} \mathrm{SO}_{4}\right)$ was added. Then cuvette is inverted and carbon monoxide bubbled again for an additional $20 \mathrm{sec}$. Immediately after $\mathrm{CO}_{2}$ bubbling, the cuvette is tightly capped. Reference cuvette is treated only with a few milligrams of sodium dithionate and mixed well.

The spectrum is recorded from $400 \mathrm{~m} \mu$ to $500 \mathrm{~m} \mu$. Cytochrome P450 quantity is calculated from the optical density difference and the molar extinction coefficient of $91 \mathrm{mmol}^{-1} \mathrm{~cm}^{-1}$. The quantity is calculated per mg of protein as per the below formula [26].

$$
\frac{\text { Optical density difference } \times 1000}{91 \times \text { Mg of protein }}=\text { mumoles of Cytochrome P450 }
$$

\section{RESULTS}

\section{Acute toxicity study}

The MPCC showed toxic effect or death at the dose of $3500 \mathrm{mg} / \mathrm{kg}$, b.w., p. o. in mice whereas MSCC showed a lethal effect at 2500 $\mathrm{mg} / \mathrm{kg}$ b.w., p. o. The $\mathrm{LD}_{50}$ value of $\mathrm{CuB}$ was $8 \mathrm{mg} / \mathrm{kg}$ b.w., p. o.

\section{TLC profile of MPCC and MSCC}

There were distinctive TLC profiles of the seed and pericarp extracts. One phenolic antioxidant and five terpenoid compounds were characteristic to the pericarp extract whereas two phenolic and one terpenoid antioxidant were characteristic to the seeds extract (fig. 2). The study able to give a guide in isolating the antidiabetic compound. Chromatogram sprayed with Vanillin $/ \mathrm{H}_{2} \mathrm{SO}_{4}$ and viewed under the $\mathrm{UV}_{254}$ light showed terpenoidal compounds as pink or blue bands. Chromatogram sprayed with $\mathrm{FeCl}_{3}$ showed phenolic compounds as dark blue bands.

TLC profile of pericarps extract of TLC profile of seeds extract of
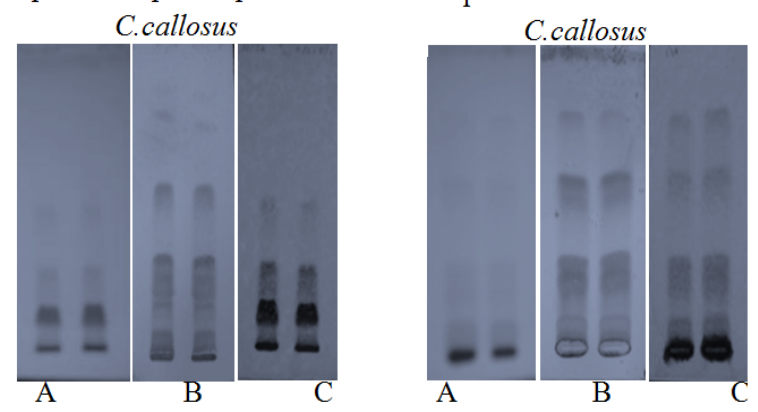

Fig. 2: (a) Chromatogram viewed under UV 254 light. (b) Chromatogram sprayed with Vanillin $/ \mathrm{H}_{2} \mathrm{SO}_{4}$. (c) Chromatogram sprayed with $\mathrm{FeCl}_{3}$ and DPPH spraying reagent

\section{Column chromatographic, UV and FTIR spectrophotometric} profile of the extract

Fraction numbers 13-17 were found to show a single spot on TLC with different types of solvent system. This compound was termed as compound-1. Further gradient elution gave another compound (compound-2) infraction numbers 26-36. They were further characterized by UV, IR studies.

The UV spectra showed $\lambda_{\max }$ of compound-2 is $226 \mathrm{~nm}$ and is a white crystalline solid with a melting point is $186-188^{\circ} \mathrm{C}$ The compound-2 was compared with the reported works on different species of Cucurbitaceae family and it was found to be Cucurbitacin-B because Cucurbitacin-B is also white crystalline solid having mixed melting point $186-188{ }^{\circ} \mathrm{C}, \lambda_{\max } 226 \mathrm{~nm}$, and FTIR peaks at 3500,2950 and $1690 \mathrm{Cm}^{-1}$ (fig. 3,4) [31]. Similarly, compound-1 was compared with the reported works and found to be Ebenone leucopentaacetate which is a brownish crystalline solid with mixed melting point 185$188^{\circ} \mathrm{C}, \lambda_{\max } 222$ and $327 \mathrm{~nm}[32]$.
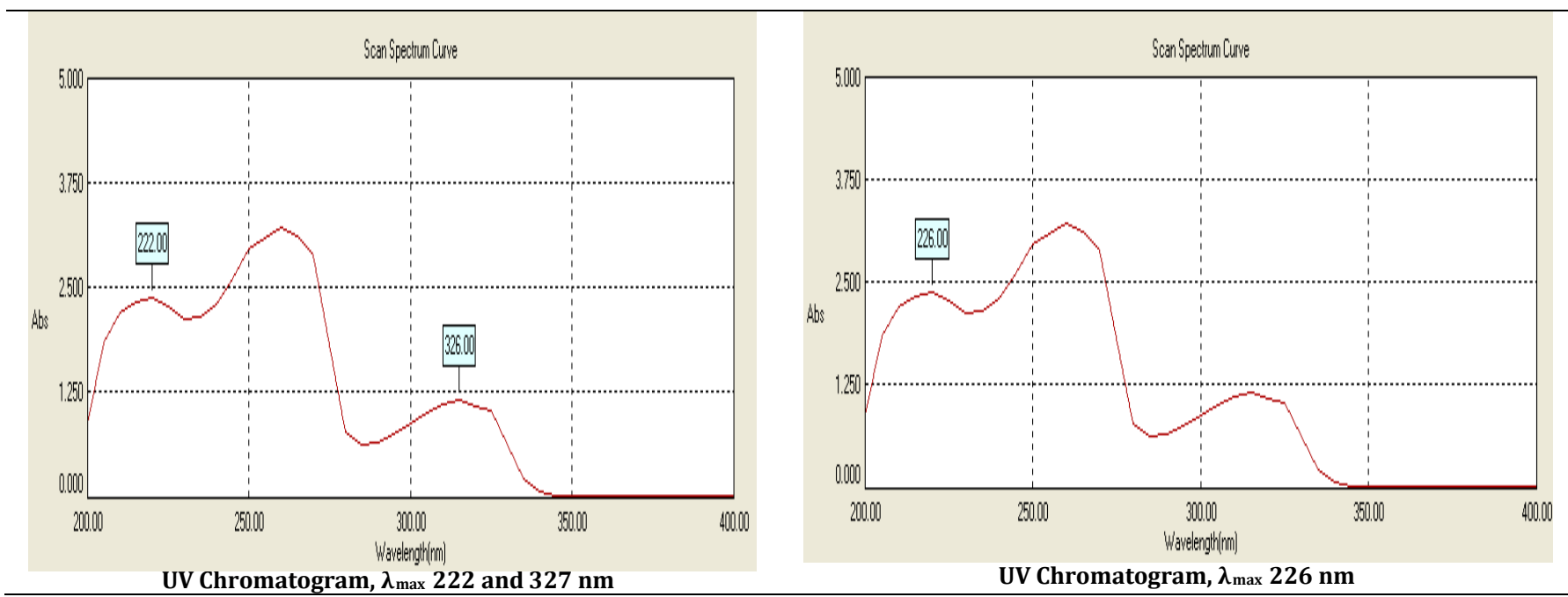

Fig. 3: UV Spectrophotometric determination of Ebenone leucopentaacetate and cucurbitacin-B 


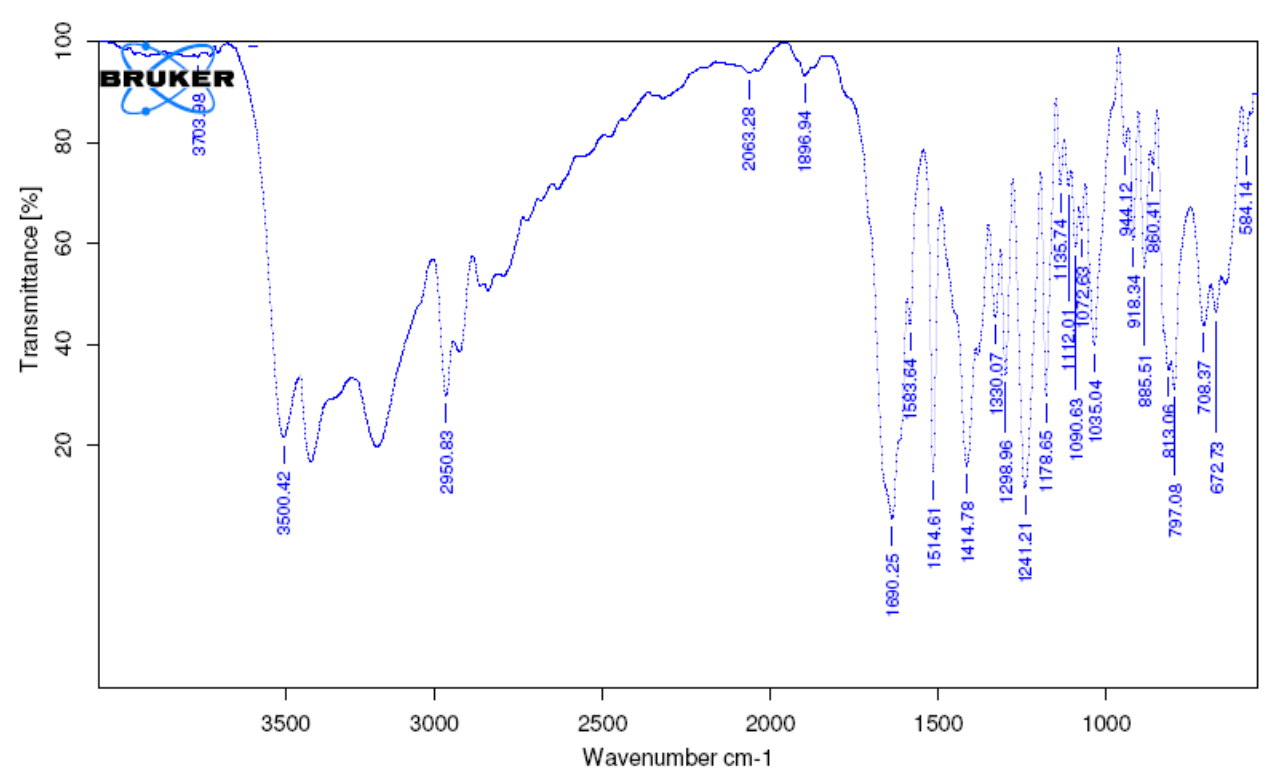

Fig. 4: FTIR spectra of cucurbitacin-B

\section{Spectrophotometric determination of cytochrome P450}

Lamda max: $454 \mathrm{~nm}$; Absorbance: 0.122

Optical density difference (400-500 $\mathrm{m} \mu): 0.122$
Mg of protein in a cuvette: 2.5

The quantity of CYP450 is $\frac{0.122 \times 1000}{91 \times 2.5}=0.53 \mathrm{~m} \mu$ moles per $\mathrm{mg}$ of protein. It showed maximum absorption at $454 \mathrm{~m} \mu$.

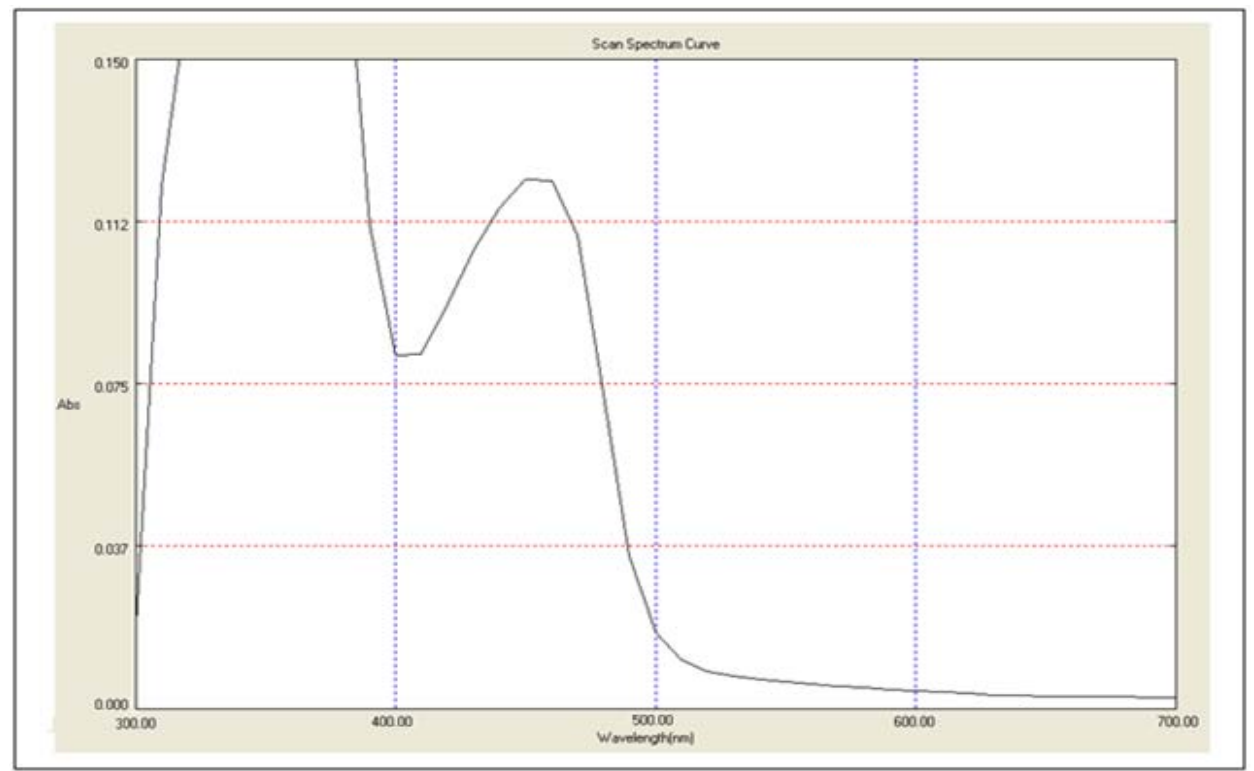

Fig. 5: UV Spectrophotometric determination of microsomal CYP 450 of rat enterocytes

Table 1: Effect of MPCC, MSCC, and CuB on fasting blood glucose (FBG) level in STZ induced diabetic rats

\begin{tabular}{|c|c|c|c|c|c|}
\hline \multirow[t]{2}{*}{ Group } & \multirow[t]{2}{*}{ Dose } & \multicolumn{4}{|c|}{ Blood glucose level mg/dl } \\
\hline & & $\mathbf{0} \mathbf{d}$ & $5^{\text {th }} d$ & $10^{\text {th }} \mathrm{d}$ & $15^{\text {th }} d$ \\
\hline I (Saline control) & $5 \mathrm{ml} / \mathrm{kg}$ (oral) & $75.00 \pm 2.88$ & $75.50 \pm 4.65$ & $74.66 \pm 2.62$ & $77.60 \pm 2.80$ \\
\hline II (STZ) & 55 mg/kg (b.w. i. p.) & $287.45 \pm 22.80$ & $298.32 \pm 36.47$ & $302.44 \pm 52.68$ & $314.08 \pm 86.17$ \\
\hline III (STZ+MPCC) & $350 \mathrm{mg} / \mathrm{kg}$ (b.w. p. o) & $280.20 \pm 43.16$ & $218.48 \pm 52.39$ & $87.52 \pm 14.65^{*}$ & $70.86 \pm 12.70^{*}$ \\
\hline IV (STZ+MSCC) & $250 \mathrm{mg} / \mathrm{kg}$ (b.w. p. o) & $278.50 \pm 28.86^{*}$ & $258.65 \pm 21.82 *$ & $190.50 \pm 28.65$ & $157.46 \pm 7.80$ \\
\hline $\mathrm{V}(\mathrm{STZ}+\mathrm{CuB})$ & $80 \mu \mathrm{g} / \mathrm{kg}$ (b.w. p. o) & $266.83 \pm 17.62$ & 118. $45 \pm 18.25$ & $118.75 \pm 8.60^{*}$ & $110.36 \pm 8.84^{*}$ \\
\hline $\mathrm{V}(\mathrm{STZ}+$ Metformin $)$ & $25 \mathrm{mg} / \mathrm{kg}$ (b.w. p. o) & $290.83 \pm 11.94$ & $138.48 \pm 12.65$ & $88.70 \pm 6.20 *$ & $78.65 \pm 8.14^{*}$ \\
\hline
\end{tabular}

Values are expressed as mean \pm SEM from $n=6,{ }^{*} \mathrm{p}<0.001$ compared with STZ-control group. 
Table 2: Effects of MPCC, MSCC, and cucurbitacin-B on the uptake of varying concentrations of glucose by gut sacs of rats

\begin{tabular}{|c|c|c|c|c|c|}
\hline \multirow{2}{*}{$\begin{array}{l}\text { Glucose } \\
\text { Concentration (mM) }\end{array}$} & \multirow{2}{*}{$\begin{array}{l}\text { Uptake }(\mu \mathrm{mol} / \mathrm{g} \text { tissue } \\
\text { wet } w \mathrm{t} / \mathrm{h}) \text { Control }(\mathrm{n}=6)\end{array}$} & \multicolumn{4}{|c|}{ Uptake $(\mu \mathrm{mol} / \mathrm{g}$ tissue wet medium/h $(\mathrm{n}=6)$} \\
\hline & & $\begin{array}{l}\text { Cucurbitacin-B } \\
(0.4 \mu \mathrm{g} / \mathrm{kg})\end{array}$ & $\begin{array}{l}\text { MPCC } \\
(1.4 \mathrm{mg} / \mathrm{kg})\end{array}$ & $\begin{array}{l}\text { MSCC } \\
(1 \mathrm{mg} / \mathrm{kg})\end{array}$ & $\begin{array}{l}\text { Metformin } \\
(0.1 \mathrm{mg} / \mathrm{kg})\end{array}$ \\
\hline 5.5 & $60.86 \pm 3.42$ & $38.23 \pm 1.54^{*}$ & $35.28 \pm 1.54^{*}$ & $60.86 \pm 3.42$ & $41.63 \pm 1.54^{*}$ \\
\hline 6.5 & $66.25 \pm 3.23^{*}$ & $40.66 \pm 1.54^{*}$ & $38.20 \pm 1.27$ & $66.25 \pm 3.23 *$ & $42.17 \pm 1.54^{*}$ \\
\hline 7.5 & $78.45 \pm 4.42^{*}$ & $45.48 \pm 1.54$ & $45.26 \pm 2.32 *$ & $78.45 \pm 4.42 *$ & $52.30 \pm 1.54$ \\
\hline 8.5 & $98.00 \pm 2.13$ & $62.18 \pm 1.54^{*}$ & $56.30 \pm 1.37 *$ & $98.00 \pm 2.13$ & $70.18 \pm 1.54^{*}$ \\
\hline
\end{tabular}

The gut sacs were incubated in Kerbs-henseleit buffer $(\mathrm{pH}=7.4)$ at $37^{\circ} \mathrm{C}$. Values are expressed as mean $\pm \mathrm{SD}$ of six experiments. $* \mathrm{P}<0.0001 . \mathrm{n}=$ number of sacs used.

Table 3: Effect of MPCC, MSCC, and cucurbitacin-B: kinetic parameters of the transport of D-glucose at different concentrations (5.5-8.5) across the rat gut sacs

\begin{tabular}{lll}
\hline Experiments $(\mathbf{n}=\mathbf{6})$ & $\mathbf{V}_{\max }(\mathbf{m M} \mathbf{M})$ & $\mathbf{K}_{\mathbf{m}}(\mathbf{m} \mathbf{M})$ \\
\hline Control & 0.0828 & 20.74 \\
Cucurbitacin-B $(0.4 \mu \mathrm{g} / \mathrm{kg})$ & 0.072 & 21.68 \\
MPCC $(1.4 \mathrm{mg} / \mathrm{kg})$ & 0.066 & 23.52 \\
MSCC $(1 \mathrm{mg} / \mathrm{kg})$ & 0.081 & 20.85 \\
Metformin $(0.1 \mathrm{mg} / \mathrm{kg})$ & 0.078 & 22.65 \\
\hline
\end{tabular}

$\mathrm{K}_{\mathrm{m}}$ and $\mathrm{V}_{\max }$ values were obtained from Line weaver-Burk Plot. $\mathrm{K}_{\mathrm{m}}$ : Michaelis-Menton constant, which is the affinity of the transferring enzyme for the substrate. $V_{\max }$ : Maximal velocity, which is the rate of transfer reaction, in the presence as well as in the absence of extract determined from the differences of uptake and release values using Michaelis-Menten and Lineweaver-Burk Plots in Microsoft Excel.

\section{DISCUSSION}

Our previous report demonstrated in vitro hypoglycemic and antimicrobial activity of Cucumis callosus (Rottl.) Cogn. Fruits and assumed that high content of phenolic compounds terpenoids and flavonoids in the extract may be a contributing factor towards hypoglycemic activity [33]. Our current research isolated a triterpenoid named Cucurbitacin-B from Methanolic Pericarp Extract of $C$ callosus (MPCC) and evaluated it's in vivo and ex vivo hypoglycemic activity. Here it is established that the hypoglycemic action of Cucurbitacin-B is due to its potential induction of novel protein such as CYP450 in enterocytes of Swiss albino rats. Ex vivo SPIP technique using different animal species including rat, rabbit, pig, dog, and monkey has been reported in the literature to study the intestinal absorption of drugs. Among these animal models, SPIP in the rat is a well-established technique to study the intestinal passive absorption of drugs with good correlation between human and rat intestinal absorption [34].

Cytochrome P450 (CYP450) enzymes belong to a superfamily of heme-thiolate containing proteins that can metabolize a wide variety of substrates [35]. The expression pattern of CYPs is very broad in terms of tissue selectivity. However, the liver is the main organ comprising the highest abundance and largest amount of individual CYPs. Substantial amounts of CYPs can also be found in the intestine, lung, kidney, brain, adrenal gland, gonads, heart, nasal and tracheal mucosa, and the skin, which may contain the highest expression of certain CYP isoforms [36]. The function of Cytochrome $\mathrm{P} 450 \mathrm{~s}$ is not only limited to xenobiotic metabolism but also have roles in endobiotic functions, mainly in sterol, fatty acid, eicosanoid and lipid-soluble vitamin (A and D) metabolism. In addition, there are several CYPs whose substrates are yet to be identified and which may be potential endobiotic metabolizing enzymes [37]. CYP enzymes catalyze a wide variety of reactions. A common feature is that CYPs can through the iron in their heme group react with molecular oxygen $\left.\mathrm{CO}_{2}\right)$ using NADPH as a cofactor, resulting in the formation of an oxidized substrate and water as a by-product. The most common reactions that the CYPs catalyze include carbon hydroxylation, heteroatom oxygenation, heteroatom release (dealkylation), epoxidation and aromatic hydroxylation, but some more complex reactions also exist [38].

Errico et al., 2011, found significant Peroxisome proliferatoractivated receptor- $\gamma$ coactivator 1- $\alpha$ (PGC-1 $\alpha)$ levels in the entire gastrointestinal tract. Notably, PGC- $1 \alpha$ is localized in the differentiated enterocytes that belong to the apical compartment of the epithelium. PGC1 $\alpha$ induction helps to maintain mitochondrial integrity, enhance intestinal barrier function, and decrease inflammation. Depletion of PGC- $1 \alpha$ in the intestinal epithelium contributes to inflammatory changes through a failure of mitochondrial structure and function as well as a breakdown of the intestinal barrier, which leads to increased inflammation and bacterial translocation [39]. Xenobiotic and endobiotic metabolizing CYP450 enzymes regulated by PGC- $1 \alpha$ and also, PGC- $1 \alpha$ is induced by metformin [38]. Metformin, a biguanide oral antihyperglycaemic agent, is widely used in the management of patients with T2D, particularly in those overweight and obese as well as those with normal renal function. It lowers the blood glucose concentration without causing hypoglycemia [40]. An increase in anaerobic metabolism in the intestinal wall is also probably a clinically significant antihyperglycaemic mechanism of metformin [41, 42]. Low dose metformin improves hyperglycemia better than acarbose in type 2 diabetics [43]. So the overexpression of CYP450 in the intestinal epithelium by MPCC and CuB is due to induction of PGC-1 $\alpha$ in the apical compartment of the epithelium, which enhance intestinal barrier function and increase anaerobic metabolism of glucose.

The small intestine is mostly dominated by CYP3A, in particular, CYP3A4 and CYP3A5 [44]. The reduced pigment form of P-450 readily combines with carbon monoxide to form a complex having an absorption maximum at $450 \mathrm{~m} \mu$ and a minimum of $405 \mathrm{~m} \mu$. Thus, its presence can be detected spectrophotometrically only as a difference-spectrum in its carbon monoxide derivative form [45]. Presence of CYP450 protein in rat enterocytes is observed from its maximum absorption at $454 \mathrm{~m} \mu$.

Glucose uptake into the cells across the cell membrane is dependent on the concentration gradient between the extracellular medium (e. g. blood plasma, gastrointestinal contents) and the cell interior. However, because glucose is such an important metabolite, there exist a number of membrane transport pumps or facilitators in certain tissues $[46,47]$. The Michaelis-Menten constant $\left(\mathrm{K}_{\mathrm{m}}\right)$ of the glucose uptake was calculated for all the experiments. $K_{m}$ is the affinity of the transferring enzyme for the substrate. In the present study, it is simulated that $\mathrm{K}_{\mathrm{m}}$ is the affinity of the CYP450 enzyme. The maximal velocity $\left(\mathrm{V}_{\max }\right)$ is regarded as the glucose uptake rate in the presence as well as in the absence of plant extract. The decreased $V_{\max }$ and increased $\mathrm{K}_{\mathrm{m}}$ in the presence of extract indicated that the affinity of transmembranal efflux glucose transport was significantly increased and velocity of glucose transport decreased [26]. So it is confirmed that the Cucurbitacin-B of pericarp extract may exhibit hypoglycemic action by inducing CYP450 enzyme which is comparable to reference drug metformin. 


\section{CONCLUSION}

The hypoglycemic action of $C$ callosus fruit is due to the presence of Cucurbitacin $B$ in the pericarp of fruit. The mechanism of hypoglycemic action of pericarp extract is due to induction of CYP450 enzyme in enterocytes of the gut. Further research to identify the specific activity of P450 isoenzymes could further develop and also complement this tool. This study also buttresses the claim that Cucurbitacin-B $(80 \mu \mathrm{g} / \mathrm{kg})$ could be used as effective therapy for the management of postprandial hyperglycemia with minimal side effects.

\section{ACKNOWLEDGMENT}

We thank Dr. Pallab Kanti Haldar, Associate Professor of Jadavpur University, Kolkata for helpful comments on the manuscript. Also, thanks to the authority of "KL Deemed to be University" for providing us all facility for successful completion of research work.

\section{AUTHORS CONTRIBUTIONS}

SPP carried out the design, conduct of the study, ex vivo and in vivo analysis and wrote the manuscript.

SPP conducted the preparation of SD extracts and chromatographic analysis.

\section{AKS collected fruits and prepared the extract.}

UPP conducted and analyzed spectrophotometric experiments.

SPP and UPP participated in the data analysis.

Both authors read and approved the final manuscript.

\section{CONFLICT OF INTERESTS}

The authors declare no conflict of interest

\section{REFERENCES}

1. Inzucchi SE, Bergenstal RM, Buse JB, Diamant M, Ferrannini Ele, Nauck M, et al. Management of hyperglycemia in type 2 diabetes: a patient-centered approach. Position statement of the American diabetes association (ADA) and the European association for the study of diabetes (EASD). Diabetes Care 2012;35:1364-79.

2. Chen C, Cohrs CM, Stertmann J, Bozsak R, Speier S. Human beta cell mass and function in diabetes: recent advances in knowledge and technologies to understand disease pathogenesis. Mol Metab 2017;6:943-57.

3. Huang THW, Peng G, Kota BP, Li GQ Yamahara J, Roufogalis BD, et al. The anti-diabetic action of Punica granatum flower extract: activation of PPAR-c and identification of an active component. Toxicol Appl Pharmacol 2005;207:160-9.

4. Neyenwe EA, Jerkins TW, Umpierrez GE, Kitabchi AE. Management of type 2 diabetes: evolving strategies for the treatment of patients with type 2 diabetes. Metabolism 2011;60:1-23.

5. Malviya N, Jain S, Malviya S. Antidiabetic potential of medicinal plants. Acta Pol Pharm Drug Res 2010;67:113-8.

6. Lorenzati B, Zucco C, Miglietta S, Lamberti F, Bruno G. Oral hypoglycemic drugs: Pathophysiological basis of their mechanism of action. Pharmaceuticals (Basel) 2010;3:3005-20.

7. Kumar R, Arora V, Verma R, Bhandari A, Vyas P. Hypoglycemic and hypolipidemic effect of Allopolyherbal formulations in streptozotocin-induced diabetes mellitus in rats. Int J Diabetes Mellitus 2015;3:45-50.

8. Hui H, Tang G, Go VL. Hypoglycemic herbs and their action mechanisms. Chinese Med 2009;4:1-11.

9. Chen H, Guo J, Pang B, Zhao L, Tong X. Application of herbal medicines with a bitter flavor and cold property on treating diabetes mellitus. J Evidence-Based Complementary Altern Med 2015:1-7. http://dx.doi.org/10.1155/2015/529491

10. Cao H, Sethumadhavan K, Grimm CC, Ullah AHJ. Characterization of a soluble phosphatidic acid phosphatase in bitter melon (Momordica charantia). PLoS One 2014;9:1-10.

11. Rathore M. Nutrient content of important fruit trees from arid zone of Rajasthan. J Horticulture Forestry 2009;1:103-8.
12. Raut M. Glimpses of nature series (No.4) our monsoon plants, Bombay Natural History, Society. Bombay, India; 1959.

13. Singh DK. Cucurbits. In: Underutilized and underexploited horticulture crops; 2007. p. 175-93.

14. Kirtikar KR, Basu BD. Indian medicinal plants. M/S Periodical Experts; New Delhi; 1984. p. 1585-8.

15. Seliya AR, Patel NK. Ethnomedicinal uses of climbers from saraswati river region of patan district, North Gujarat. Ethnobotanical Leaflets 2009;13:865-72.

16. Rahman AHMM. Ethno-medicinal investigation on the ethnic community in the northern region of Bangladesh. Am J Life Sci 2013;2:77-81.

17. Patil DA, Patil PS, Ahirrao YA, Aher UP, Dushing YA. Ethnobotany of buldhana district (Maharashtra: India): Plants used in veterinary medicine. J Phytol 2010;12:22-34.

18. Panda SP, Chakraborty M, Majumder P, Mazumder S, Das S, Haldar PK. The antidiabetic, antioxidant and antihyperlipidemic activity of Cucumis callosus in streptozotocininduced diabetic rats. Int J Pharm Sci Res 2016;7:1978-84.

19. Trivedi PC. Medicinal plants: traditional knowledge. In: Sharma UK, Gogoi J. eds. Ethno-Medico-Botany of some sacred plants of Dhemaji district of Assam, IK International Pvt. Ltd., New Delhi; 2006. p. 102.

20. Issa RM, Khedr AM, Rizk HF. UV-vis, IR and $H$ NMR spectroscopic studies of some schiff bases derivatives of 4aminoantipyrine. Spectrochim Acta Part A 2005;62:621-9.

21. Thangaraj P. Preliminary phytochemical studies. In: Pharmacological assays of plant-based natural products. Prog Drug Res 2016;71:15-9.

22. Iszard MB, Curtis JL, Klaassen D. Effet of several metallothionein inducers on oxidative stress defense mechanisms in rats. Toxicology 1995;104:325-33.

23. Kumar A, Sutharson L, Shrivastava TP, Bhattacharya S, Haldar PK. Hypoglycemic activity of Erythrina variegata leaf in streptozotocininduced diabetic rats. Pharm Biol 2011;49:577-82.

24. Franco M, Lopedota A, Trapani A, Cutrignelli A, Meleleo D, Micelli $\mathrm{S}$, et al. Rat intestinal sac as an in vitro method for the assessment of intestinal permeability in humans: application to carrier transported drugs. Int J Pharm 2008;352:182-8.

25. Bert NLaDu, George H, Mandel E, Leong Way. Fundamentals of drug metabolism and drug disposition. In: Mazel P. ed. Laboratory experiments in the study of drug metabolism and drug disposition, Hyderabad, India: PharmaMed Press; 2010. p. 560-75.

26. Cherksey BD, Altszuler N. On the mechanism of potentiation by morphine of thiopental sleeping time. Pharmacology 1974;12:362-71.

27. Varma MV, Panchagnula R. Enhanced oral paclitaxel absorption with vitamin E-TPGS: effect on solubility and permeability in vitro, in situ and in vivo. Eur J Pharm Sci 2005;25:445-53.

28. Patel M, Mishra S. A kinetic study for in vitro intestinal uptake of monosaccharide across rat everted gut sacs in the presence of some antidiabetic medicinal plants. Int J Altern Med 2009;7:1-7.

29. Theresa SV, Thirumalai T, Tamilselvan N, David E. In vivo and ex-vivo inhibition of intestinal glucose uptake: a scope for antihyperglycemic. J Acute Disease 2014;3:36-40.

30. Afifi MS, Ross SA, ElSohly MA, Naeem ZE, Halaweish FT. Cucurbitacins of Cucumis prophetarum. J Chem Ecol 1999;25:847-59.

31. Sankaram AVB, Reddy VVN. Structure of ebenone, a possible biogenetic precursor of elliptinone, from Diospyros ebenum. Phytochemistry 1984;23:2039-42.

32. Panda SP, Haldar PK, Das S. In vitro hypoglycemic and antimicrobial activity of Cucumis callosus (Rottl.) Cogn. fruit. Asian J Pharm Clin Res 2016;9:77-81.

33. Yerasi N, Vurimindi H, Devarakonda K. Rat intestinal perfusion to evaluate drug permeability: application to p-gp and cyp3a4 substrates. Front Pharmacol 2015;141:1-8.

34. Nebert DW, Dalton TP. The role of cytochrome P450 enzymes in endogenous signaling pathways and environmental carcinogenesis. Nat Rev Cancer 2006;12:947-60.

35. Pelkonen O, Turpeinen M, Hakkola J, Honkakoski P, Hukkanen J, Raunio H. Inhibition and induction of human cytochrome P450 enzymes: current status. Arch Toxicol 2008;82:667-715. 
36. Guengerich FP, Cheng Q. Orphans in the human cytochrome P450 superfamily: approaches to discovering functions and relevance in pharmacology. Pharmacol Rev 2011;63:684-99.

37. Guengerich FP. Common and uncommon cytochrome P450 reactions related to metabolism and chemical toxicity. Chem Res Toxicol 2001;14:611-50.

38. Errico ID, Salvatore L, Murzilli S, Sasso GL, Latorre D, Martelli $\mathrm{N}$, et al. Peroxisome proliferator-activated receptor- $\gamma$ coactivator 1- $\alpha(\mathrm{PGC} 1 \alpha)$ is a metabolic regulator of intestinal epithelial cell fate. Proc Natl Acad Sci 2011;108:6603-8.

39. Obi BC, Okoye TC, Okpashi VE, Igwe CN, Alumanah EO. Comparative study of the antioxidant effects of metformin, glibenclamide, and repaglinide in alloxan-induced diabetic rats. J Diabetes Res 2016. Doi:10.1155/2016/1635361

40. Bailey CJ, Mynett KJ, Page T. Importance of the intestine as a site of metformin-stimulated glucose utilization. $\mathrm{Br} \mathrm{J}$ Pharmacol 1994;112:671-5.

41. Song R. Mechanism of metformin: a tale of two sites. Diabetes Care 2016;39:187-9.
42. Yajima K, Shimada A, Hirose H, Kasuga A, Saruta T. Low dose metformin improves hyperglycemia better than Acarbose in type 2 diabetics. Rev Diabet Stud 2004;1:89-94.

43. Watkins PB, Wrighton SA, Schuetz EG, Molowa DT, Guzelian PS. Identification of glucocorticoid-inducible cytochromes P-450 in the intestinal mucosa of rats and man. J Clin Invest 1987;80:1029-36.

44. Ondieki G, Nyagblordzro M, Kikwete S, Liang R, Wang L, He X. Cytochrome P450 and P-glycoprotein-mediated interactions involving African herbs indicated for common noncommunicable diseases. J Evidence Based Complementary Altern Med 2017:18. Doi:10.1155/2017/2582463

45. Greene JR, Harri DN. Endocrine system. In: Pathophysiology and therapeutics for pharmacists. $3^{\text {rd }}$ edn. Great Britain: RPS Publisher; 2008. p. 582.

46. Sinko PJ, Leesman GD, Amidon GL. Predicting fraction dose absorbed in humans using a macroscopic mass balance approach. Pharm Res 1991;8:979-88. 